\section{Развитие интродуцированных видов рода Acer L. в условиях Карелии}

\author{
И. Т. Кищенко ${ }^{1}$, \\ Н. А. Клементьев, \\ М. Н. Потапова \\ Петрозаводский государственный университет
}

\section{АННОТАЦИЯ}

В статье приводятся результаты изучения особенности сезонного развития 6 интродуцированных видов Acer в таежной зоне России (южная Карелия). Установлены различия в сроках развития у разных видов растений. Обнаружено влияние температуры и влажности воздуха, атмосферных осадков и солнечной радиации на сроки наступления фенологических фаз.
\end{abstract}

Ключевые слова: клен, развитие, экологические факторы, интродукиия.

\section{SUMMARY}

Seasonal developmental features of six introduced species of Acer have been studied in the taiga zone of Russia (Southern Karelia). The real differences were discovered between species in period of fenology phase passing during vegetation. It was determined, that growing process of studied species of Pinus depended on the air temperature and moisture, atmosphere precipitations and sun activity.

Keywords: Acer, development, introduction, ecological factors.

Знание фенологических особенностей конкретного вида растений позволяет устанавливать наиболее благоприятные сроки посева и посадки, сбора семян, борьбы с вредителями, болезнями и др. Особое значение эти исследования имеют для интродукции растений: на их основе можно объективно оценить перспективность интродуцентов $[9,11,12]$.

Целью исследований являлось установление особенностей развития интродуцированных видов Acer в условиях Карелии для оценки адаптированности и перспективности экзотов. Подобные исследования в Карелии ранее не проводились.

\section{МАТЕРИАЛ И МЕТОДИКА}

Наблюдения проводились с 1976 по 1989 гг. в Ботаническом саду Петрозаводского государственного университета, расположенном на северном берегу Петрозаводской губы Онежского оз. (подзона средней тайги). Объектами исследований служили представители

\footnotetext{
${ }^{1}$ Авторы - соответственно профессор, д.б.н.; студент V к. и агроном Ботанического сада ПетрГУ

() И. Т. Кищенко, Н. А. Клементьев, М. Н. Потапова, 2003
}

6 видов рода Acer: Acer platanoides, A. pseudoplatanus, A. ginnala, A. negundo, A. semenovii, A. tataricum. Фенологические наблюдения проводились с учетом методических указаний ряда авторов $[1,2,4,5]$, через каждые 2-3 сут. Фиксировали время прохождения таких фенофаз, как набухание и разверзание вегетативных почек, начало и окончание линейного роста побегов, обособление листьев на побегах, завершение роста и вызревание, расцвечивание и опадение листьев, обособление и разверзание генеративных почек. Фенофаза считалась наступившей, если она отмечалась не менее чем у 30 \% побегов всех особей исследуемого вида.

Климатические факторы регистрировали на метеостанции, расположенной в 3 км к юго-западу от Ботанического сада. По результатам многолетних наблюдений сформировали банк данных, обработанный с помощью рекомендуемых для этих целей статистических методов $[6,7,8]$.

\section{РЕЗУЛЬТАТЫ ИССЛЕДОВАНИЙ И ИХ ОБСУЖДЕНИЕ}

Анализ данных статистической обработки показал, что ошибка средней многолетней величины фенодат весьма незначительна и, как правило, не превышает 12 сут.

Исследования показали, что ритмика сезонного развития изучаемых видов Acer имеет свои специфические особенности. По среднемноголетним данным, быстрее всего (1-2 V) набухание вегетативных почек начинается у A. negundo и A. tataricum, а у других видов - на 4-6 сут. позже. Разверзание вегетативных почек быстрее всего наступает у A. negundo $(9 \mathrm{~V})$, следующими в данную фазу вступают A. semenovii, A. tataricum, A. ginnala $(12-15 \mathrm{~V})$. Позже всех в данную фазу вступают A. platanoides и A. pseudoplatanus (17-21 V).

Линейный рост побегов отмечается через 25-30 сут. после начала набухания вегетативных почек (25-31 V), причем у A. pseudoplatanus на 8 сут. позднее, чем у других видов (9 VI). Этот процесс заканчивается позже всего (28 VII) у A. semenovii, а у других видов на 3-13 сут. раньше.

Наиболее ранние сроки (3-4 VII) опробковения оснований побегов отмечаются у $A$. ginnala и $A$. platanoides, а у других видов - на 6-12 сут. позже. Процесс опробковения побегов по всей длине у $A$. negundo заканчивается позже всех (22 VIII), у всех остальных видов на 11 сут. раньше.

Раньше всех (18 V) начинается обособление листьев у A. negundo. Позже всех вступает в эту фенофазу A. pseudoplatanus $(30 \mathrm{~V})$. У остальных видов данная фаза начинается 21-23 V. Завершается рост листьев у изучаемых видов в июле, причем ранее всех (6 VII) у $A$. platanoides. У других видов завершение роста листьев происходит в период 10-20 VII. Первыми в фазу расцвечивания листьев (12-14 IX) вступают A. negundo и A. platanoides, а остальные виды - спустя 1-2 недели. Быстрее всего (4-5 X) начинают опадать листья у $A$. 
negundo и A. platanoides. У прочих видов эти фенофазы начинаются на 4-8 сут. позже.

Фаза обособления генеративных почек на побегах скорее всех $(10-15 \mathrm{~V})$ наступает у $A$. negundo и $A$. platanoides, а у A. tataricum - позже всех (27 V). Раньше всех $(15 \mathrm{~V})$ разверзание почек происходит $y A$. negundo, а позже всех ( VI) - у A. tataricum. У других видов эта фенофаза имеет место $23 \mathrm{~V}-1$ VI. Скорее всех в фазу бутонизации вступают $A$. negundo и $A$. platanoides (20-25 V). У остальных видов данная фенофаза начинается на 20-25 сут. позднее.

Наиболее ранние сроки (25 V-2 VI) начала цветения отмечаются у A. negundo и A. platanoides, а у других видов - на месяц позже (24-25 VI). Процесс окончания цветения этих двух видов также начинается раньше всех (3-13 VI), у всех остальных видов - на месяц позже (13-17 VII).

Первыми в фазу завязывания плодов вступают $A$. negundo и A. platanoides (30 V-8 VI), остальные виды - 5-11 VII. Позже всех в фазу созревания плодов вступают A. negundo и A. tataricum (6-9 IX), у остальных видов плоды созревают на неделю раньше - 2631 VIII. Раньше всех плоды опадают у A. ginnala и A. negundo (20-21 IX). Позже всех в данную фазу вступает A. platanoides (16 X).

Таким образом, приведенные данные показывают, что изучаемые виды клена по особенностям ритмики сезонного развития условно можно разделить на 2 группы: рано начинающие и заканчивающие развитие $(A$. platanoides и A. negundo) и поздно начинающие и заканчивающие развитие (остальные виды). При этом очередность прохождения фенофаз у изучаемых видов Acer из года в год не меняется.

Авторы многочисленных исследований $[9,11]$ убедительно показали, что особенности развития различных видов растений обусловлены их неодинаковой требовательностью к экологическим факторам. Поэтому, определив диапазон толерантности основных фенофаз к экологическим факторам, можно судить о степени адаптации данного вида растений к условиям местообитания. При анализе состояния среды во время начала фенофаз обнаружена очень сильная погодичная вариабельность значений относительной влажности воздуха, атмосферных осадков и суммарной солнечной радиации, что свидетельствует об отсутствии искомой зависимости.

Между тем температурный режим воздуха в момент наступления очередной фенофазы за исследуемый период оставался довольно стабильным и заметно отличался у разных видов растений. Так, набухание вегетативных почек у разных видов клена начинается при почти одинаковой среднесуточной температуре воздуха $5.5-7.4^{\circ} \mathrm{C}$. Однако начало данной фенофазы у A. platanoides и A. ginnala наблюдается при более высоких значениях температур - соответственно $8.3{ }^{\circ} \mathrm{C}$ и $9.2^{\circ} \mathrm{C}$. Разверзание вегетативных почек у A. negundo и
A. tataricum происходит при более низкой температуре $\left(7.5-8{ }^{\circ} \mathrm{C}\right)$, чем у остальных видов $\left(9.6-12.5^{\circ} \mathrm{C}\right)$.

Начало линейного роста побегов при самых низких показателях теплообеспеченности $\left(10.8-11.7{ }^{\circ} \mathrm{C}\right)$ отмечается у A. platanoides и A. semenovii. На втором месте по данным показателям все остальные виды $\left(12.2-13.9^{\circ} \mathrm{C}\right)$. Заканчивается данная фенофаза у всех изучаемых видов при значениях температуры воздуха, близких к $15.4-17.3^{\circ} \mathrm{C}$.

Опробковение оснований побегов начинается у $A$. platanoides при более низкой температуре $\left(14.8{ }^{\circ} \mathrm{C}\right)$, чем у других видов $\left(15.8-17.6^{\circ} \mathrm{C}\right)$. Фаза опробковения побегов по всей длине у A. negundo начинается при более низких значениях температуры $\left(11.8^{\circ} \mathrm{C}\right)$, чем у других видов $\left(13.8-15.4^{\circ} \mathrm{C}\right)$.

Обособление листьев на побегах начинается при повышении температуры до $10.7-13.1{ }^{\circ} \mathrm{C}$. Завершение роста и вызревание листьев происходит у всех видов при температуре $15.6-16.7{ }^{\circ} \mathrm{C}$. Расцвечивание листьев при температуре $9-10.4{ }^{\circ} \mathrm{C}$ происходит у A. negundo и A. platanoides. Менее требовательны к данному параметру среды в эту фенофазу A. semenovii, A. pseudoplatanus и A. ginnala $\left(5.8-6.8^{\circ} \mathrm{C}\right)$, и особенно A. tataricum $\left(3.5^{\circ} \mathrm{C}\right)$. Опадание листьев при более высокой температуре $\left(-0.3-0.5{ }^{\circ} \mathrm{C}\right)$ отмечено у A. platanoides и A. negundo. У остальных видов данная фенофаза заканчивается при более низкой температуре (-8.5-4.9 $\left.{ }^{\circ} \mathrm{C}\right)$.

Выяснилось, что обособление генеративных почек у A. negundo и A. platanoides начинается при более низких значениях температуры $\left(9.7-10{ }^{\circ} \mathrm{C}\right)$, чем у других видов $\left(11.9-12{ }^{\circ} \mathrm{C}\right)$. Фазы разверзания генеративных почек и бутонизации начинаются при почти одинаковых значениях температур $\left(11.4-13.3^{\circ} \mathrm{C}\right)$.

Начало цветения у A. negundo наступает при более низких значениях температуры $\left(10.6^{\circ} \mathrm{C}\right)$, чем у других видов $\left(13.2-15.8^{\circ} \mathrm{C}\right)$. Фаза окончания цветения у $A$. platanoides и A. negundo проходит при температуре 13.2-14.1 ${ }^{\circ} \mathrm{C}$, у остальных видов - при более высокой температуре $\left(16-16.8^{\circ} \mathrm{C}\right)$.

Фаза завязывания плодов при самых низких показателях теплообеспеченности проходит у A. negundo и $A$. platanoides (13.1-13.5 ${ }^{\circ} \mathrm{C}$ ), у остальных видов - при температуре $16.3-17.4{ }^{\circ} \mathrm{C}$. Созревание плодов проходит у изучаемых видов при близких значениях температуры - 9.3-11.6 ${ }^{\circ} \mathrm{C}$. У A. platanoides опадание плодов наблюдается при температуре $4.7^{\circ} \mathrm{C}$, у остальных видов - при более теплой погоде $\left(5-7.7^{\circ} \mathrm{C}\right)$.

\section{ВЫВОДЫ}

1. Сроки наступления всех фенофаз у изучаемых видов Acer в значительной мере зависят от температурного режима воздуха.

2. Наиболее ранние сроки начала и окончания развития характерны для A. negundo, что свидетельствует о повышенной степени адаптированности 
данного вида, а значит, и о наибольшей перспективности для озеленения.

\section{СПИСОК ЛИТЕРАТУРЫ}

1. Бейдеман И. Н. Методика изучения фенологии растений и растительных сообществ. Новосибирск, 1974. $154 \mathrm{c}$.

2. Булыгин Н. Е. Фенологические наблюдения над древесными растениями. Л., 1979. 97 с.

3. Ворошилов В. Н. Ритм развития растений. М., 1960. $135 \mathrm{c}$.

4. Елагин И. Н. Методика проведения и обработки фенологических наблюдений за деревьями и кустарниками в лесу // Фенологические методы изучения лесных биогеоценозов. Красноярск, 1975. С. 3-20.

5. Фенологические наблюдения (организация, проведение, обработка). Л., 1982. 223 с.

6. Зайцев Г. Н. Краткое пособие по математической обработке данных фенонаблюдений. М., 1972. 7 с.
7. Зайцев Г. Н. Комплексная оценка надежности результатов массовых фенологических наблюдений // Методы современной биометрии. М., 1978. C. $113-118$.

8. Зайцев Г. Н. Фенология древесных растений. М., $1981.119 \mathrm{c}$.

9. Лапин П. И. Научные основы и результаты интродукции древесных растений // Журн. общ. биол. 1977. № 5. С.781-793.

10. Методика фенологических наблюдений в ботанических садах СССР // Бюл. ГБС АН СССР. 1979. Вып. 113. С. 3-8.

11. Плотникова Л. С., Губина Е. М. Рост и развитие древесных растений в культуре // Сезонный ритм интродуцированных древесных растений флоры СССР в ГБС АН СССР. М., 1986. С. 127-149.

12. Сабинин Д. А. Физиология развития растений. М., 1966. 195 c. 